\title{
Civil Society and the European Union in Times of Crisis: From Partnership to Threat?
}

\begin{abstract}
The article analyses the changes in the interaction between the EU institutions and civil society organizations. The article first sets the conceptual stage by examining the role of civil society in the political arena and specifically in the context of the Europeanization. It then identifies 3 major phases of European activism: 1) 19932001, the period in which institutional channels were opened for civil society at the European level; 2) 2001-2014, the period in which civil society played a full role within the EU governance; 3) 2014 to present day, in which the emergence and consolidation of anti-EU establishment civil society has become a central political issue for the EU. Three specific European master frames are
\end{abstract}

analyzed, before the focus is shifted to the global level. Concluding remarks are presented on the critical issue and the future prospect for the EU with reference to the impact of social mobilization from below in a context of crisis.

KEYWORDS: European Union, Civil Society, Governance, Globalization, Economic Crisis

FOR CITATION: Marchetti R. (2017). Civil Society and the European Union in Times of Crisis: From Partnership to Threat? Outlines of global transformations: politics, economics, law, 10 (1). 106-121. DOI: 10.23932/25420240-10-1-106-121

\section{Гражданское общество и Европейский Союз во времена кризиса: от партнерства к угрозе?}

АННОТАЦИЯ. В статье проанализированы изменения взаимодействия институтов ЕС и гражданских структур. Исследуя роль гражданского общества на политической арене и в особенности в контексте европеизации, автор начинает статью рядом кониептуальных замечаний. После этого в статье выявлены 
три фазы политического участия в ЕС: 1) 1993-2001, период, в который институциональные площзадки были максимально открыты для гражданского участия на европейском уровне; 2) 2001-2014, период, в который гражданское общество играло самостоятельную роль в структуре управления ЕС; 3) 2014 по настоящий момент, период, характеризуюшийся повышенным вниманием $\kappa$ появлению и консолидации анти-ЕС истеблишмента в структурах гражданского общества. В статье проанализированы три важнейших фрейма, характерных для ЕС, после чего исследовательский фокус переносится на глобальньй уровень. В заключении автор представляет ряд критических замечаний о проблемах и перспективах ЕС, принимая во внимание влияние социальной мобилизаиии в контексте кризиса.

КЛЮЧЕВЫЕ СЛОВА: Европейский Союз, гражданское общество, государственное управление, глобализация, экономический кризис

ДЛЯ ЦИТИРОВАНИЯ: Маркетти Р. (2017). Гражданское общество и Европейский Союз во времена кризиса: от партнерства к угрозе. Контуры глобальных трансформаций: политика, экономика, право, 10 (1). 106-121. DOI: 10.23932/25420240-2017-10-1-106-121

\section{Introduction}

With the financial crisis came a political epiphany in European society. As a consequence of the economic crisis a number of national political systems have changed dramatically. The popular support for traditional parties has sharply declined. New populist parties have boomed. Major economic policies have been "agreed externally" within European and international institutions. Trans-ideological coalition governments have been created, with both conservative and progressive parties sharing power.

Sticking to a traditional paradigm of left and right politics we would not be able to provide an account of such changes. Specific circumstances or tactical decisions provide only partial explanations. While at a first sight such changes may appear contingent, I will argue that they ultimately reveal a fundamental transformation of politics in the age of globalization. The crisis is revealing a new political constellation that cannot be comprehended with the old categories that helped us to give a meaning to our XX century experience.

The article suggests that the post-crisis events reveal a fundamental transformation of politics that is rooted and here to stay for some time. A transformation that concerns the main political cleavage of globalization. While in the past, the dichotomy was between left and right (Bobbio, 1994; reprinted 1996), today the key tension is centered in-between supranational integration and national preservation in the economic, social and political realm. Between global democracy and rooted democracy, between supranational politics and national politics. It is with reference to issues such as market integration, delegation of sovereignty, participation to regional organizations, but also the acceptance of "universal" standards that we can better understand the political divisions of today, where the action is.

With this, I don't want to suggest that the traditional principles associated with the right-wing or left-wing understanding of politics are of no value, or no use anymore. Normatively, they still play an important function in guiding the assessment of many political decisions (e.g. equality versus individual freedom from state intervention). However, what I want to suggest is that these ideological points of reference are of little use when we need to decipher the fundamental policy decisions taken by national or international actors. What really matters there is the attitude towards globalization, 
which does not coincide with the positioning of political parties along the left-right continuum. In today's politics, the first thing is to settle the ultimate framework, i.e. to decide where to stand in relation to the issue of globalization. Once this is done, the realm of traditional left vs. right politics emerges. Normative disputes, I submit, come only later in the discussion.

In the last thirty years, we have been living, in the west and later on in the rest of the world, in a system in which the fundamental decisions in favor of globalization have been taken for granted. They have not been really discussed either in national or regional parliaments, or in the public debates. They have been simply taken as a given. The consensus in the establishment has been so widespread that the old Thatcherite say of TINA (there is no alternative) seems almost fully realized by now. Once these fundamental decisions are set conjunctively, then secondary political disputes may arise. Left and right wing parties may then compete even harshly for winning the electorate, provided the ultimate pro-globalization position is left aside from the political agon and kept as a common, unquestionable background. Current politics is characterized by a competition that is not ultimate, for it ultimately lays on a common platform.

It is precisely in the age of crisis as the one we are living in, with the emergence of new parties and anti-establishment movements, that the debate on the ultimate issue of globalization re-emerges. And it is in this moment that we can more clearly see the fundamental political splits characterizing our polities. During the current financial crisis, the political debates moved from secondary issues to key macro-economic and (eminently) political decisions, that have to do with the positioning of a country vis-à-vis the global and regional economic-political integration.

Accordingly, the political ideological framework changed dramatically. In many European countries we have by now transideological governments in which center-left and center-right parties sharing power in the name of the European orthodoxy, and we have the oppositions that share a common anti-European establishment attitude. From a mainstream perspective, based on the traditional left vs. right split, these governments cannot easily be explained. An alternative, more convincing way to look at it is by adopting the perspective of the debate on globalization. From this perspective, what was unclear becomes crystalline. The parties supporting these governments, regardless of their ideological affiliation, are all parties that share an overall pro-globalization and pro-Europe attitude. With minor differences, they all agree that is imperative to comply with the international and European standards of good governance, even if this means ceding part of the national sovereignty and paying high social costs. Political and economic integration is considered a default position, which promises widespread benefits in the mid/long-term.

On the contrary, the parties that are at the opposition to these governments are all "localist". While having very different ideological orientations, they share the view according to which the local/regional context needs to be prioritized. They share a suspicion of any process that dismantles this rooted, participatory context in the name of supranationalism. Political and economic integration is here considered an elite-driven project that ultimately benefits the transnational centers of power by making the local contexts weaker and poorer. Especially serious is the progressive deprivation of political resources that is allegedly associated to the process of supranational integration. From this perspective, the more you delegate power higher and further, the less you are able to democratically control it.

This way, the politics of crisis is revealing the inner nature of the political cleavage underpinning many contemporary western political systems. In normal times, such fundamental cleavage may be more difficult to be seen because it is taken for granted and 
rarely discussed: politics usually plays on a more superficial playing field. It is especially in times of deep crisis, however, that the fundamental cleavage emerges. It is in these times that we can better understand the contours of the political framework of many political systems and understand what is really at stake in our polities.

This paper intends to shed light on the transforming conceptual landscape that draws the boundaries of the current political debate both at the national and international level. It does so by focusing on the normative debate on globalization and by examining the principal master frames that have been developed in the last decades with reference to European politics. In the EU context, we can distinguish at least three main political frames, as regional specification of the abovementioned master frames. The euroenthusiastic frame proposes a positive assessment of the European development, and detects some problems in the implementation of the project, which is believed to be resulting from the EU institutions. The critical Europeanist frame searches for a more social and democratic Europe rather than the Europe of markets. The euro-skeptic frame tends to read the regional integration process as a set of detrimental dynamics that threatens the communitarian bases necessary for the sustainability of the local and national political projects. This frame is a more local and nationalist interpretation of the European integration, which is perceived as a direct intervention in the sovereignty of the nationstates. The specific European masterframes cannot be fully understood without a reference to the global debate. For this reason, the article makes also reference to the four master frames that delimit the boundaries of the current ideational debate on global politics, especially after the financial crisis. Two approaches are pro-integration (neo-liberalism and cosmopolitan) and two are against integration (localism and civilizationism). It suggests that this set of master frame helps us in understanding the current political scenario, thereby including the different stances vis a vis the Eurozone crisis.

The paper proceeds according to the following structure: it first sets the conceptual stage by examining the role of civil society in the political arena and specifically in the context of the Europeanization. It then identifies 3 major phases of European activism: 1) 1993-2001, the period in which institutional channels were opened for civil society at the European level; 2) 2001-2014, the period in which civil society played a full role within the EU governance; 3) 2014 to present day, in which the emergence and consolidation of anti-EU establishment civil society has become a central political issue for the EU. Three specific European master frames are analyzed, before the focus is shifted to the global level. Concluding remarks are presented on the critical issue and the future prospect for the EU with reference to the impact of social mobilization from below.

\section{The Europeanization of civil society}

The mainstream understanding of civil society sprung from specific historical, political and socio-economic backgrounds. The early philosophical debates on civil society emerged from and were grounded in Western Europe, in contexts of state formation (Hobbes, Locke, and Ferguson), emerging capitalism and class struggle (Hegel and Marx), democratization and democracy (Gramsci and Habermas). Likewise, in the 1970s and 1980s civil society activity and literature was firmly grounded in the West, having played an active role in issues such as nuclear disarmament, environmental sustainability and gender and race struggles. The more recent wave of civil society literature since the end of the Cold War is also mostly grounded in the West, this time couched in the wider framework of globalization and in- 
ternational relations studies. A specific, more recent, trend in the study of civil society concerns the process of Europeanization. This study fits into this latter trend.

The specific contexts in which these literatures are embedded are often taken for granted. Rarely are the implications of context in the development of civil society openly acknowledged and taken into account (Lewis, 2001; Marchetti \& Tocci, 2009). Yet a study of the role of civil society in the wider Europeanization process must account for the role and implications of context. Hence a first variable in this analysis of civil society in conflict is the context within which it operates. In this respect, several core questions need to be raised at the outset. Can and does civil society exist in contexts beyond the traditional background of the state? The underlying premise of this chapter is that civil society can and does exist in these situations. Yet its nature as well as its role and functions are fundamentally shaped by the specific context in question. Insofar as civil society is both an independent agent for change and a dependent product of existing structures, we are likely to encounter a wide range of civil society actors carrying out a wide range of actions in this context.

\section{Figure 1: The position of civil society}

\section{a. Civil society as a sector}

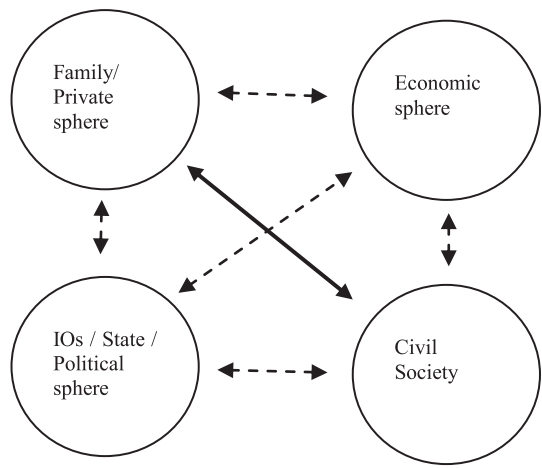

While the standard definition of civil society identifies it as the space outside of the government, the family, and the market in which individuals and collective organizations advance allegedly common interests in a competitive environment (see fig. 1 below), a more encompassing definition understands civil society as referring to the sphere in which citizens and social initiatives organize themselves around objectives, constituencies and thematic interests with a public nature, be it local, national or transnational. Accordingly, civil society organizations usually include community groups, non-governmental organizations (NGOs), social movements, labor unions, indigenous groups, charitable organizations, faith-based organizations, media operators, academia, diaspora groups, lobby and consultancy groups, think tanks and research centers, professional associations, and foundations (with political parties and private companies remaining the most controversial cases). An even wider definition of non-state actors includes also criminal networks, terrorists, and combatant groups. Analytically, four broad categories of civil society organizations (CSOs) can be distinguished: membership organizations, interest organizations, service organizations, and support organizations.

\section{b. Civil society as an intermediate sphere}

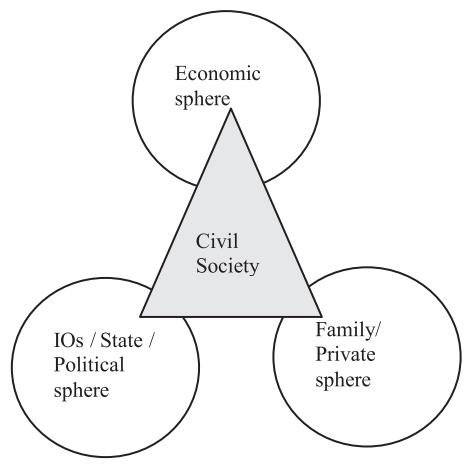


The term civil society was rediscovered after the fall of the Wall and was intensely deployed in the policies formulation in the laboratory in Central and Eastern Europe, but also in Latin America, and East Asia. In this context, a particularly important dimension of the action of civil society organizations was its relation with the state. In general terms, this relation is seen alternatively as either competitive, or cooperative. According to the first perspective deriving from J. Locke, popular control of political institutions requires an external, independent actor, and civil society constitutes a fitting functional counterpart to the institutional power. On the opposite, according to the tradition of cooperation inspired by Montesquieu and Hegel, civil society is seen in its integrative function either as cooperating with the institutions in terms of inputs (CSOs have an associative function that generate legitimacy of the state, close to communitarianism) or as a subcontractor for facilitating the outputs. From this perspective, the sense of community and solidarity is grounded in the life-world. CSOs have precisely the role of transmitting such sense into the public institutions: they are intermediaries, but at the same time they are also constitutive of the social cement underpinning any political endeavor.

In particular, for what concerns the relation between civil society and democracy, CSOs are usually seen as democracy enhancers. According CSOs are expected to play a significant role in the different phases of the democratic transition. In the moment of liberalization of the autocratic regime, CSOs are usually united in the strategic fight against the ancient regime. In the phase of institutionalization of democracy, they tend to cooperate for the building of the new regime. And finally, in the process of consolidation of democracy, CSOs are understood as schools of democracy, contestation and pluralism, as in the reflexive function. It should be noted, however, that such democratic reading of civil society is normatively biased insofar as it precludes the possibility to analyze the whole range of actors engaged in politics from a nongovernmental stance. It is usually based on a very specific notion of what a "good" CSOis, thus excluding from the radar many politically significant organizations. Hence, it is important to recognize that the contribution to democracy enhancement may come from many different directions and through indirect paths.

In the context of the EU, civil society is usually understood in a functionally broad way, though it may be limited in political terms. It is functionally broad in that definitions of civil society usually include different kinds of interest groups: non-governmental organizations; social movements; advocacy and promotional groups; functional interest groups as social partners (such as trade unions and employers' organizations); sectoral organizations (such as entrepreneurs' and consumers' associations), but also universities, research institutes and epistemic communities. In the $\mathrm{EU}, \mathrm{CSO}$ are usually expected to play the collaborative role (as in opposition to being a force of opposition) within a procedural manner in the policy-making process. As we will see, EU procedures tend to favors a functional out-put oriented conception of civil society involvement. For this reason, politically antagonist groups are usually marginalized, if not ostracized and even criminalized.

From a civil society perspective, the process of Europeanization has to be understood as a complex European integration process that transforms actors and make them supranationally part of a single demos, a single public space in which CSOs interact transnationally. More formally, Radaelli interpret Europeanization as a "construction; diffusion; and the institutionalization of formal and informal procedures, rules and ways of doing things, shared beliefs and norms, which are first defined and consolidated in the EU policy process and then incorporated into the logic of domestic discourses, identities, political structures and public policies" 
(Radaelli, 2003, p. 30). In sum, it is a process (of diffusion, learning, adjusting, and the reorientation of politics), and effect (of engagement with Europe), a cause (of further integration); and relation (between the EU and other actors) (Boronska-Hryniewiecka, 2011).

\section{EU's openings to civil society (1993-2001)}

The topic of civil society participation entered the EU agenda after the foundation of the European Union in 1993 with the Maastricht Treaty. Setting the goal of the political union, the treaty indirectly generated the debate on the democratic deficit and more generally on the increasing politicization of the EU integration process. That signaled the end of the "permissive consensus" on the elite-driven, from that moment on the previously de-politicized process of the EU integration became more contentious (Hooghe \& Marks, 2009). In this context, participation of civil society became more and more essential from the point of view of both CSOs and practitioners who saw CSOs as a solution, as legitimacy enhancer, to solve their problems. Together with civil society, the other legitimacy enhancing strategy was to strengthen the European Parliament and shifting on the overall from out-put to input dimension of legitimacy.

The European Commission has a long story of consultation with civil experts, but it changed and expanded its attitude over time (Quittkat \& Finke, 2008). In the 1960s and 1970s the Commission focused on "consultation" within the European economic integration and dialogue with primarily economic experts within industrial and agrarian interest groups ${ }^{1}$. Other CSOs were still outside of the interaction with the EEC, except the long standing Europe movements of the federalists.
Later on in the 1980s and 1990s the Commission focused on developing a "partnership" with nongovernmental actors within the social dialogue on specific policy areas such as security, social and educational policy. While the Commission demanded greater participation of civil society, European civil society itself expanded its reach to the regional level. A multitude of associations opened their branches in Brussels, such as the European Trade Union Confederation. Better IT technologies and improved European coordination facilitated the scale shift towards the EU level.

However, only in the 1990s and 2000s the attention moved to the idea itself of "participation" and the concept of participatory democracy (Economic and Social Committee, 1999). The White Paper on Governance drew the framework for such cooperation (European Commission, 2001) and the Leaken Conference of 2001 established a qualitative milestone for the recognition of the participation of NGOs in European governance by including for the first time the representation of civil society in the Convention working on the Constitutional Treaty. The most recent development in the integration of civil society is constituted by the Lisbon Treaty which further enhances the European Social Dialogue and institutionalizes citizens' initiatives. Today, "Your Voice in Europe", online consultation system offers the opportunity for all recorded groups to express a view during the Commission's policy formulation phase. As a result, the process of policy formation widened beyond the classical intergovernmental method and included voluntary, informal, inclusive, and participatory forms of coordination, the so called new era of the EU multilevel governance.

These transformations in the EU attitude towards civil society created a structure of opportunities that CSOs repeatedly used to influence the decision-making process at the

1 In 2009, there were 1,316 EU-level interest representatives on the EC register, with approximately 60 per cent stemming from business and trade associations and the rest representing diffuse or public interests. 
European level. In fact, we can expect that "the more political decisions are dispersed, the more open (and less repressive) a system is considered. The prevalent assumption is that the greater the number of actors who share political power (the more the checks and balances), the greater the chance that social movements will emerge and develop" (Della Porta \& Caiani, 2009, p. 7). The EU governance structure tends to be fairly open to the inputs of civil society, if compared with similar political regimes throughout the world. While it is pretty clear by now that the system is more open to conventional, pragmatic lobbying than to ideological and disruptive action, it still leaves room for windows of opportunities for different kinds of mobilizations on different levels. Depending on the circumstances, CSOs may for instance adopt strategies of either domestication (putting pressure on the national constituencies) or externalization (targeting the EU institutions) to adapt better to the political opportunity structure that is presented to them, or indeed alternatively adopting a multiple strategy in which both the local and the European level is targeted. Especially in specific sectors such as the definition of the EU democracy and human rights external policies, civil society has played a significant role in setting the agenda. A recent case in point is represented by the successful mobilization of the LGBT groups that managed to include their political goals in the official agenda of the EIDHR.

\section{Civil society organizations within European governance (2001-2014)}

With the full implementation of the EU governance model, civil society organizations have played a growing role in EU affairs. The debate on the specific role played by CSOs within the European governance system is very intense (Schutter, 2002; Rumford, 2003; Ruzza, 2005). Two are the principal alternatives in the reading of the functions assigned and played by CSO within the EU system: functional collaborator or constitutive source for the creation of a European public space, as summarized in Table 1 below.

Table 1. Two main political interpretation of the role played by civil society

\begin{tabular}{|c|c|c|}
\hline & $\begin{array}{l}\text { Collaborator of public } \\
\text { bodies }\end{array}$ & $\begin{array}{l}\text { Constitutive source for trans-European } \\
\text { public space }\end{array}$ \\
\hline $\begin{array}{l}\text { Modes } \\
\text { of interaction }\end{array}$ & $\begin{array}{l}\text { Multi-stakeholder } \\
\text { partnership }\end{array}$ & Deliberative Europeanization \\
\hline $\begin{array}{l}\text { Official } \\
\text { documents }\end{array}$ & $\begin{array}{l}\text { White Paper } \\
\text { on Governance, } \\
2001\end{array}$ & $\begin{array}{l}\text { Convention methods applied in the European Charter of Fundamen- } \\
\text { tal Rights 2000, European Convention 2001-2003, the Treaty on a } \\
\text { Constitution for Europe 2003, and later on the Treaty of Lisbon } 2009\end{array}$ \\
\hline $\begin{array}{l}\text { Types } \\
\text { of CSOs }\end{array}$ & $\begin{array}{l}\text { Organized interests, interest } \\
\text { intermediation and lobbying }\end{array}$ & $\begin{array}{l}\text { Civil society as a whole, but also as a site } \\
\text { of contestation }\end{array}$ \\
\hline Functions & $\begin{array}{l}\text { Partners, not expected to } \\
\text { control accountability }\end{array}$ & $\begin{array}{l}\text { Public sphere as both open participation } \\
\text { and challenge to public authority }\end{array}$ \\
\hline Activities & $\begin{array}{l}\text { Service provision in a demand- } \\
\text { offer scheme }\end{array}$ & $\begin{array}{c}\text { Training for social and political virtues, producing social ties and } \\
\text { social capital, and providing opportunities for mobilization and } \\
\text { collective action }\end{array}$ \\
\hline Composition & NGOs, experts, educated & Social movements, laymen \\
\hline
\end{tabular}


Among the European institutions, the European Commission has by far the greater role vis-a-vis CSOs. The European Parliament only comes second on this. The Commission deploys an activation strategy for inclusion of CSOs on the predominantly supranational policy formulation. Over the years, the Commission has tried to institutionalize NGOs structures along policy areas (NGO families) by expanding the notion of civil society as providers of information and inputs in its policy-making.The highly developed system of comitology is characterized by the extensive use of informal practices beyond intergovernmentalism, a type of problem-solving interaction, and the spill-over effect of socialization on participants (Curtin, 2003; Joerges \& Neyer, 2006).

It is by now clear that the mode of interaction of the European Commission is highly biased towards CSOs rather than less organized grass root movements. Institutionalized, professional type of CSOs are part and parcel of the functional mode of governance insofar as they act as governance partners in the implementation of sectorcomprehensive strategies on different policy levels while at the same time providing alternative, deliberative path for the re-legitimization of the EU. It is clear however that a difference remains between participatory governance (with stakeholders) and participatory democracy from below. In principle, participatory governance remains centered on an instrumental input legitimacy and an output legitimacy anchored on the privatepublic partnerships (PPPs), whereas participatory democracy is rather based on a mode of intrinsic input legitimacy in which discursive involvement in the policy formation is promoted by a growing transnational and European civil society. The Commission is currently implementing the first and only aspiring to realize the second.

Such fracture between instrument and intrinsic logic of legitimacy is also evident in the assessment of the (actual and potential) impact of CSOs towards the EU system. At times CSOs are conceived as a threat to input legitimacy as based on formally institutionalized representative democracy. Often, CSOs are seen as an asset to increase the quality of policies and services delivered by the EU (outputs), but also as a pragmatic answer to shortcomings in input legitimacy that cannot be fully overcome due to the multi-level system of governance. More rarely or rather in principle, CSOs are ideally perceived as a carrier of an emerging EU order with a genuine EU public sphere and input legitimacy in its own right. The contrast between these differing readings also entails a serious political dilemma, possibly the most crucial disfunctionality in the relation between the EU institutions and civil society: "the conditions civil society has to meet to participate limit the very virtues for which the Commission pursues its normative and material activation strategy" (Heidbreder, 2012, p. 19). The more the Commission seeks professionalized NGOs, the less it will have bottom up and contentious civil actors, which however limits the potential for fulfilling the legitimizing and communicative role of civil society. It is a sort of catch - 22 situation in which CSO need to be highly professionalized in order to have a voice in Brussels, and yet at the same time, CSOs are also supposed to remain deeply rooted in order to provide genuine legitimacy from below. It seems that all the attempts developed by the EU institutions to engage with civil society and to bridge the EU with the European citizens have simply created a pro-Brussels CSO elites working in the interests of deeper integration and left behind all the other politically significant actors. Such tension can also be noted by looking at the frames developed by CSOs with reference to the $\mathrm{Eu}$ ropean project itself. 
The emergence of anti-EU civil society (2014-today)

The Europeanization of the public sphere is growing through the development of a number of ideational references that are increasingly shaping the mobilization of civil society actors at the European level. Common framing, controversies, parallelism of themes, and cross referencing are contributing to the definition of a common and yet plural European social agenda. In this vein, "the growing Europeanization of social movements is cognitively driven: as with the nation-state, social movement organizations and actions tend increasingly to move towards the EU institutions due to a growing acknowledgment of the increasing competences of the EU, as well as a preoccupation with the direction in which the competences are used. Cognitive processes include not only the increasing shift of the target (and therefore of prognostic and diagnostic frames) towards the EU, but also a growing recognition of similarities among national causes and therefore the construction of a shared European identity" (Della Porta \& Caiani, 2009, 171).

Three main frames can be distinguished in the current, post 2014 debate among European CSOs. The predominant (at least before the eruption of the crises) frame for the political action of many CSOs is the Euroenthusiastic attitude. Despite entailing different degrees of support for the European project, the euro-enthusiastic frame proposes a positive assessment of the European development so far, and more importantly detects in the insufficient implementation of the project the actual origin of the current problems of the EU institutions. A second frame is constituted by the classic euro-scepticism. This frame suggests a reading of the regional integration process as a set of detrimental dynamics that threatens the communitarian bases necessary for the sustainability of the local and national politi- cal projects. Finally, a third growing frame is represented by the critical Europeanists. According to this, a social Europe should be strengthened in opposition to the Europe of markets. A more political Europe, it holds, is needed to counter the apolitical and elitesdriven Europe that we have known so far. The process of Europeanization is seen from this angle as developing also by contestation: a contested public debate is the surest path toward supranational legitimacy.

We cannot fully understand the European debate if we do not take into account the debate at the international and global level, which has been developing along similar lines.

\section{The Transformation of the Political Cleavage: From Left vs. Right to Supranationalist vs. Localist}

The focus of the debate on globalization is the inadequacy of the current institutional framework and its normative bases for a full development of the political sphere at the global level. Traditional political canons anchored in the nation-state and its domestic jurisdiction are increasingly perceived as insufficient, or indeed, self-defeating in a world in which socio-economical interaction is, to a significant degree, interdependent. Unstable financial markets, environmental crises, and unregulated migratory flows offer just a few examples of phenomena that all too clearly remind us of the heavy interdependence of the contemporary international system and of its political deprivation. These intense processes of global transformation functionally require increased transnational cooperation, and yet pose a continuous challenge to the effectiveness and legitimacy of "traditional" political life.

Acknowledging the limits of this political tension, alternative projects of global politics have been developed and mooted publicly in 
recent decades. Their common denominator consists of the attempt to go beyond the centrality of the sovereign state towards forms of political participation that allow for new subjects to "get into transnational politics" (Marchetti, 2016). These new would-be or quasi-global political actors are part of the broad category of non-state actors, which includes: international non-governmental organizations, transnational corporations, networks and campaigns of civil society organizations and faith-based groups, transnational social movements, transnational political parties, international private bodies, and individuals. Despite minor institutional experiments, most of these actors share the characteristics of effectively being excluded from international decision-making mechanisms, and yet being more and more active on the global stage. International exclusion constitutes the critical target of most of the alternative projects of global politics that occupy the center of the public debate on globalization.

Underpinning this debate on the political deficits of the global system are a number of ideological readings of globalization and global political phenomena that can be considered to be species of archetypes or master frames of global politics. Historically speaking, the first master frame with a global scope tended to have a rather negative outlook. In the 1970, among the very widespread negative master frames was the anti-Americanism master frame, but also that of anti-colonialism. Earlier on, the master frame of anti-Nazism was dominant. In more positive terms, the master frame of human rights also played a crucial role for many decades. We can call these first generation global master frames. They were the first and the less articulated master frames. With time, some of them lost their political centrality (e.g., the anti-Nazism frame though it is from time to time recalled) whilst some flowed into other more sophisticated global master frames. Anti-Americanism often turned into lo- calism or civilizationism; anti-colonialism partly disappeared and partly flowed into civilizationism; the master frame of human rights was further developed within the global master frames of cosmopolitanism, but also to some extent within that of localism. In order to understand better the different between first and second generation global master frames we now need to move to the current debate on the master frames of global politics.

A typical phenomenon of any transition process occurring at the international level is precisely the sense of instability generated by the emergence of un-institutionalized actors and new legitimacy claims (previously unheard) in the public domain. Within this context of new political agency, an unprecedented global public domain consolidates in which old, state-centered visions of international affairs mix with new non-statecentered visions of global politics, producing a complex map of ideological positions. The global public domain remains thus a central place where new dimensions and new applications of global legitimacy are developed and advanced in contrast to current interpretations. This does not necessarily entail reformist or indeed revolutionary transformations, but the mere possibility of starting a dynamic of norms change in international politics makes this global public arena and its ideal content extremely important for current global politics (Clark, 2007; Finnemore \& Sikkink, 1998). It is to this global public discourse and to its components that we need to look in order to understand the future, long-term transformation of global politics.

Four key interpretations of the notion of world polity can be identified as delimiting the range of non-conventional ideal alternatives available to the global political debate. Two masterframes are pro-integration and two are anti-integration. The main cleavage is therefore identified with the attitude towards supranationalism. 1) The vision of 
neoliberal capitalism as associated with a global free market and private economic actors; 2) the project for the democratization of international institutions as formulated in the cosmopolitan model with reference to individuals and supra-national institutions; 3 ) the radical vision held by the vast majority of the social movements in terms of alter-globalism and that of ethnic localism; and finally, 4) the discourse on the dialogue or clash of civilizations which refers to macro-regional actors often defined in religious terms (Marchetti, 2009, 2016). For a synthetic presentation of the specific dimensions of each master frames please refer to the table below.

\section{Table 2. Main characteristics of global master frame}

\begin{tabular}{|c|c|c|c|c|}
\hline & \multicolumn{2}{|c|}{ Globalist } & \multicolumn{2}{|c|}{ Contextualist } \\
\hline & Neo-Liberalism & Cosmopolitanism & Localism & Civilizationism \\
\hline $\begin{array}{l}\text { Reading of } \\
\text { globalization }\end{array}$ & Supportive & Reformist & Radical antagonism & Conservative antagonism \\
\hline Human bond & Economic & Political & Social & Cultural-Religious \\
\hline Agency & $\begin{array}{l}\text { Individual/Col- } \\
\text { lective (firms and } \\
\text { consumers) }\end{array}$ & Individual (citizens) & $\begin{array}{l}\text { Collective (grass- } \\
\text { roots groups) }\end{array}$ & $\begin{array}{l}\text { Collective (civilisations } \\
\text { and cultural élites) }\end{array}$ \\
\hline Ontology & $\begin{array}{l}\text { Universalism; Homo- } \\
\text { geneity }\end{array}$ & $\begin{array}{l}\text { Universalism; Homo- } \\
\text { geneity }\end{array}$ & $\begin{array}{c}\text { Pluralism; Hetero- } \\
\text { geneity }\end{array}$ & Pluralism; Heterogeneity \\
\hline $\begin{array}{l}\text { Political } \\
\text { principles }\end{array}$ & $\begin{array}{l}\text { Globalism; Tech- } \\
\text { nocracy; Sameness; } \\
\text { Freedom; Competi- } \\
\text { tion }\end{array}$ & $\begin{array}{l}\text { Globalism; Delegated } \\
\text { participation; Sameness; } \\
\text { Hierarchy; Institutional } \\
\text { fairness }\end{array}$ & $\begin{array}{c}\text { Place-basedness; } \\
\text { Direct participation; } \\
\text { Diversity; Autonomy; } \\
\text { Solidarity }\end{array}$ & $\begin{array}{l}\text { Culture-basedness; Elites } \\
\text { guidance; Diversity; } \\
\text { Respect; Goodwill and } \\
\text { non-violence }\end{array}$ \\
\hline $\begin{array}{l}\text { Institutional } \\
\text { project }\end{array}$ & $\begin{array}{l}\text { Global self-regu- } \\
\text { lation }\end{array}$ & $\begin{array}{l}\text { Supranational integra- } \\
\text { tion of individuals }\end{array}$ & $\begin{array}{l}\text { Local groups, Trans- } \\
\text { national networks }\end{array}$ & Macro-regionalism \\
\hline
\end{tabular}

\section{The future of European politics}

The history of the European integration has been characterized by a widespread consensus in the political elites of the member states. EU leaders have for the most part shared a feeling of overall support for a gradual economic integration at the regional level. At times, such support was almost unquestioned, leading to a "quasi-delegation" of decision-making power to technocratic elites. The expression of "permissive consensus" was coined to describe this situation of a de facto cession of sovereignty to supranational technocrats.
The situation changed for the first time with the Maastricht Treaty in 1993. With the restatement of the goal of the political union, the treaty indirectly generated the debate on the democratic deficit of the EU and more generally on the increasing politicization of the regional integration process. From that moment on, the previously de-politicized process of the EU integration became more contentious. A number of consequences derived from such shift, including the strengthening of the European Parliament and the inclusion of the topic of civil society participation into the EU agenda. 
A second change occurred with the Eurozone crisis that is hitting vast parts of the EU since 2009. The economic downturn provoked dramatic changes in many domestic political systems and this is likely to have a significant impact on the future European institutions, beginning with the European Parliament. At the national level, a number of governments were challenged, had to give up their leadership, or to accept alliances with the opposition parties in unprecedented trans-ideological grand coalitions. At the same time, long standing Eurosceptic parties grew and new critical political movements emerged with a clear anti EU establishment agenda. As a consequence of such shift, the European landscape appears today much more pluralistic than in the past.

While during the period of the permissive consensus there was only a limited scrutiny by European civil society on the decisions taken in Brussels, with the economic crisis and the deep social consequences suffered by so many countries, the level of attention towards the European decision-making process has steadily increased. More and more, national leaders are challenged in their positioning concerning major EU decisions, EU leaders are made object of criticism, as the EU as such is more and more seen with suspicion, if not with straightforward mistrust, by the majorities of many member states especially in the south of Europe, as indicated by the Eurobarometer data.

The new European landscape is today much more diversified than in the past. The anti-establishment camp is now stronger and more pluralistic. The new contentious politics against the euro-enthusiastic bloc is carried out by distinct angles: euro-sceptical, euro-critical and so-called "populist".

On the right-hand side of the political spectrum, there are the main euro sceptical groups that are ideologically close to the idea of ethnic nationalism. They have been present in the European landscape for a long time and have also been represented in tiny minorities within the European Parliament. After the 2014 european election, their presence in the EP has grown substantially (Hassing Nielsen \& Franklin, 2016). Examples of such groups include the Northern League in Italy, the National Front in France, the Finns Party in Finland, the Freedom Party in Austria, the Danish People's Party in Denmark, the Flemish Interest Party in Belgium, the Golden Dawn in Greece, and the British National Party in the UK.

On the left-hand side of the political spectrum, instead, there are those euro critical parties linked to the principle of vernacular and local politics as embedded in specific social traditions. They have also played a minor role in the past but have now accentuated their contentious positioning towards the EU, especially its elites-driven, neo-liberal policies (della Porta, Fernández, Kouki, \& Mosca, 2017). Examples of such groups include the Greek Communist Party in Greece, the fractions of the former Italian Communist Party in Italy, and the French Communist Party in France. The support to both of these two categories of political groups, eurosceptic and eurocritical, has been boosted by the economic crisis.

Beyond the aforementioned groups that have been present in the European landscape for many years by now, a number of new political parties and social movements that were born or grew substantially after the crisis should also be taken into consideration. These groups have often electorally benefitted more than the previously mentioned parties of the economic downturn. These groups tend to have a most radical oppositional stance towards the EU, with a populist vein often associated to an explicit anti-euro attitude and a call for a more participatory democracy. Differing examples of such groups include the Five Star Movement in Italy, the Indignados movement in Spain, and to some extent Syriza in Greece. 
The present European Parliament elected in 2014 is much more pluralistic than the previous one. Two consequences derive from this. On the one hand, it is more difficult to reach consensual decisions. The classical consensual mode of many European institutions is moving to a majoritarian or two-track approach, if effectiveness is pursued. On the other hand, the presence of so many anti-establishment, if not anti-euro, parties forces the traditional euro-enthusiastic parties (mainly PPE and Socialists) to coalesce even more explicitly than they used to do in the past. A scenario of this kind is already occurring at the national level of many member states. A trans-ideological majority including all major proEuropean integration groups, i.e., the European People's Party (EPP), the Party of the European Socialists (PES), and perhaps the Alliance of Liberals and Democrats for Europe (ALDE). And a mixed opposition with the right-wing nationalist parties, the leftwing critical parties, and the new populist movements. This might also suggest a more difficult task for advocates of pro-austerity measures to uphold their policies. In sum, the Eurozone crises has been a game changer in many member states as well as at the EU level.

The effects of the economic crisis on the European society are generating a number of significant political consequences. Brexit is the most obvious result of popular discontent exacerbated by the economic crisis. In a similar vein, in many other European countries anti-establishment political parties are gaining popularity, often by manipulating the issue of migration and islamophobia. As a consequence, both national and European institutions are under continuous attack. European democracy as we have known it in the last three decades is eroding, with clear evidences of a worsening performance of many elements of the quality of democracy, including socioeconomic rights, political participation, equality, inter-institutional accountability, and the resulting overall responsiveness of the system to the inputs of the citizens. The future ahead is very uncertain. Much will depend on the economic performance of the euro-area. However, this will not only be a matter of economics. Deep political dynamics are under way, which will be difficult to stop. These may either reinvigorate the democratic debate at both the national and European level or push the system towards competitive nationalism with dangerous consequences.

If we go back to the Eurozone crisis, we can understand better the different political reaction we have witnessed in the recent times and the transformation of the political landscape in Europe. On the one hand, we find those who argue that the crisis is mainly due to malfunctioning of the system and requires a technical remedy which tends to be value neutral. These is the typical response of the globalist and pro-integration positions. They may then differentiate between an allegedly value neutral position more in line with the neoliberal master frame, and a more political position closer to the master frame of cosmopolitanism. On the opposite camp, we find those who argued that the crisis is due to an adhesion to an economic model that is inherently flawed and injustice generating. The solution of these lays in a profound change in the nature of the economic, especially financial, integration ongoing at the European level. Both the master frame of localism and that of civilizationism concur in holding that ethical corrections need to be made to the current economic globalization at the regional level. With this, the specific political transformations occurring in many European political systems are referred back to larger socio-economic processes that have to do with the phenomena of globalization. 


\section{References}

Bobbio N. (1994). Left and Right. The Significance of a Political Distinction. Cambridge: Polity. 148.

Boronska-Hryniewiecka K. (2011). Europeanization of Non-State Actors: Towards a Framework for Analysis. Armstrong D., Bello V., Gilson J., Spini D. (eds.). Civil Society and International Governance. The Role of Non-State Actors in Global and Regional Regulatory Frameworks. London: Routledge. 73-91.

Clark I. (2007). International Legitimacy and World Society. Oxford: Oxford University Press. 224. DOI: 10.1093/acprof :oso/9780199297009.001.0001

Curtin D. (2003). Private Interest Representation or Civil Society Deliberation: A Contemporary Dilemma for European Governance. Social and Legal Studies, 12 (1). 55-75. DOI: 10.1177/0964663903012001844

Della Porta D., Caiani M. (2009). Social Movements and Europeization. Oxford: Oxford University Press. 230. DOI: 10.1093/ac prof:oso/9780199557783.001.0001

Della Porta D., Fernández J., Kouki H., Mosca L. (2017). Movement Parties Against Austerity. Cambridge: Polity. 246.

Economic and Social Committee. (1999). Opinion of the Economic and Social Committee on 'The Role and Contribution of Civil Society Organizations in the Building of Europe'. Brussels: CES 851/1999 (1999/C 329/10).

European Commission. (2001). European Governance: A White Paper. COM (2001) 428 final.Brussels.

Finnemore M., Sikkink K. (1998). International Norms Dynamics and Political Change. International Organization, 52 (4). 887-917. DOI: 10.1162/002081898550789

Hassing Nielsen J., Franklin M. N. (eds.). (2016). The Eurosceptic. 2014 European Parliament Elections: Second Order or Second Rate? London: Palgrave. 265. DOI: 10.1057/978-1-137-58696-4_12
Heidbreder E. G. (2012). Civil Society Participation in EU Governance. Living Reviews in European Governance, 7 (2). 1-42. DOI: 10.12942/lreg-2012-2

Hooghe L., Marks G. (2009). A Postfunctionalist Theory of European Integration: From Permissive Consensus to Constraining Dissensus. British Journal of Political Science, 39 (1). 1-23. DOI: 10.1017/ s0007123408000409

Joerges C., Neyer J. (2006). Deliberative Supranationalism. Revisited. European University Institute. Working Paper LAW20. DOI: $10.2139 /$ ssrn. 963334

Lewis D. (2001). Civil Society in NonWestern Contexts: Reflections on the Usefulness of a Concept. Civil Society Working Paper series, 13. Centre for Civil Society. London: London School of Economics and Political Science.

Marchetti R. (2009). Mapping Alternative Models of Global Politics. International Studies Review, 11 (1). 133-156. DOI: 10.1111/j.1468-2486.2008.01828.x

Marchetti R. (2016). Global Strategic Engagement. States and Non-State Actors in Global Governance. Lanham: Lexington Books. 210

Marchetti R., Tocci N. (2009). Conflict Society: Understanding the Role of Civil Society in Conflict. Global Change, Peace and Security, 21 (2). 201-217. DOI: 10.1080/14781150902872091

Paffenholz T. (ed.). (2010). Civil Society and Peacebuilding. A Critical Assessment. Bouder: Lynne Rienner. 511.

Quittkat C., Finke B. (2008). The EU Commission Consultation Regime. KohlerKoch B., De Bievre D., Maloney W. (eds.). Opening EU-Governance to Civil Society: Gains and Challenges. Mannheim: University of Mannheim. 183-222.

Radaelli C. (2003). The Europeanization of Public Policies. Featherstone K., Radaelli C. (eds.) The Politics of Europeanization. Oxford: Oxford University Press. 27-56. DOI:10.1093/0199252092.003.0002 
Rumford C. (2003). European Civil Society or Transnational Social Space? Conceptions of Society in Discourses of EU Citizenship, Governance and the Democratic Deficit: An Emerging Agenda. European Journal of Social Theory, 6 (1). 25-43. DOI: $10.1177 / 1368431003006001555$

\section{About the author}

Raffaele Marchetti, Senior Assistant Professor in International Relations, Libera Universitá Internazionale degli Studi Sociali, Guido Carli

Viale Romania, 32, Rome, 00197, Italy rmarchetti@luiss.it
Ruzza C. (2005). Europe and Civil Society: Movement Coalitions and European Governance. Manchester: Manchester University Press. 221.

Schutter O. de (2002). Europe in Search of Its Civil Society. European Law Journal, 8 (2). 198-217. DOI:10.1111/1468-0386.00150

\section{Сведения об авторе}

Раффаэле Маркетти, доцент (международные отношения) факультета политических наук, Libera Universitá Internazionale degli Studi Sociali, Guido Carli

00197, Италия, Рим, Viale Romania, 32 rmarchetti@luiss.it 